\title{
Crenated Cell Measurement
}

National Cancer Institute

\section{Source}

National Cancer Institute. Crenated Cell Measurement. NCI Thesaurus. Code C74703.

The determination of the number of crenated red blood cells present in a sample. 